\title{
Water and air ozone treatment as an alternative sanitizing technology [abstract]
}

\author{
Mauro Martinelli1, Francesca Giovannangeli1, Sara Rotunno1, Claudia Maria \\ Trombetta1', Emanuele Montomoli²
}

1Department of Internal Medicine, Ospedale San Pietro FbF, Rome, Italy, 2Department of Molecular and Developmental Medicine, University of Siena, Italy

\section{ABSTRACT}

\section{OPEN ACCESS}

\section{Citation}

Martinelli M, Giovannangeli F, Rotunno $\mathrm{S}$, Trombetta CM, Montomoli E. Water and air ozone treatment as an alternative sanitizing technology [abstract]. Proceedings of The World Conference on Ozone Therapy in Medicine, Dentistry and Veterinary. Ancona (Italy). September 22nd - 23rd - 24th , 2017. J Ozone Ther. 2019;3(4):23. doi: 10.7203/ jo3t.3.4.2019.15426

Academic Editor Jose Baeza-Noci, School of Medicine, Valencia University, SPAIN

\section{Editor}

World Federation of Ozone Therapy, Bolgna, ITALY

\section{Received}

June 17, 2019

\section{Accepted}

December 08, 2019

\section{Published}

December 30, 2019

Intellectual Property

Mauro Martinelli.

This is an open access article distributed under the terms of the Creative Commons Attribution License (CC BY 4.0), which permits unrestricted use, distribution, and reproduction in any medium, provided the original author and source are credited.

\section{Author Information}

Corresponding Author:

Dr. Francesca Giovannangeli.

Osp. S.Pietro Fbf, via cassia 600,

Roma Tel. 392/1329421

Email: fra.giovannangeli@gmail.com
Purpose: Investigate the effectiveness of ozone treatment as an alternative sanitizing technology to conventional disinfectants in reducing the microbial contamination of both water and air.

Patients and methods: Ozone was added for 20 minutes to a well-defined volume of water and air by the system named "Ozonomatic ${ }^{{ }^{\circledR}}$. The effectiveness of ozonation was determined by counting $\mathrm{CFU} / \mathrm{m}^{3}$ or $\mathrm{ml}$ of bacteria present in samples of air or water collected before (T0) and after (T1) the addition of ozone and comparing the microbial load of different bacteria present in ozonized and non-ozonized samples.

Results: When the ozonation equipment was located at $30 \mathrm{~cm}$ from the surface of the water in the bath tub in which the bacteria were inoculated, the treatment was able to reduce the microbial load present in the aerosol by $70.4 \%$ at a temperature of $36^{\circ} \mathrm{C}$ for 48 hours. Conversely, at $22^{\circ} \mathrm{C}$ for 5 days, only a modest decrease $(9.1 \%)$ was observed. Escherichia coli and Pseudomonas aeruginosa were completely eliminated. A 93.9\% reduction was observed for Staphylococcus aureus, followed by Streptococcus faecalis (25.9\%). The addition of ozone to water was able to almost eliminate Staphylococcus aureus (98.9\% reduction) and also to exert a strong impact on Legionella pneumophila (87.5\% reduction). Streptococcus faecalis and Pseudomonas aeruginosa showed a decrease of $64.2 \%$ and $57.4 \%$, respectively. Conversely, only a $26.4 \%$ reduction was observed for the bacterium Escherichia coli. This study showed that the addition of ozone in the air exerted a modest reduction on microbial load at $36^{\circ} \mathrm{C}$, whereas no effect was observed at $22^{\circ} \mathrm{C}$.

Conclusion: Aqueous and gaseous ozone treatments were effective against microbial contaminants, reducing the CFU of the microorganisms and confirming its efficacy in water and air disinfection. 